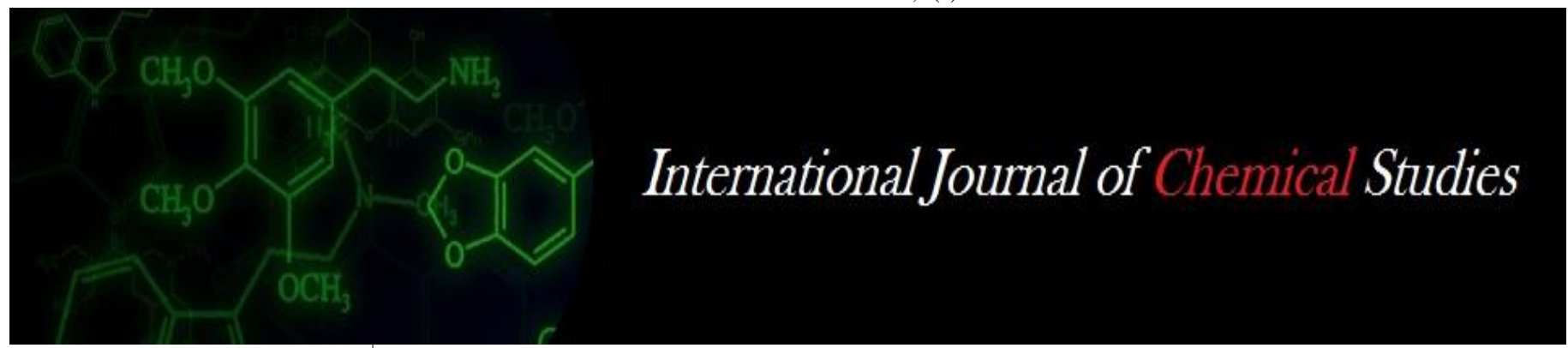

P-ISSN: 2349-8528

E-ISSN: 2321-4902

www.chemijournal.com

IJCS 2020; 8(3): 2453-2456

(C) 2020 IJCS

Received: 25-03-2020

Accepted: 26-04-2020

Sushree Choudhury

Krishi Vigyan Kendra Ganjam-

II Odisha University of

Agriculture and Technology,

Odisha, India

Debasis Sarangi

Krishi Vigyan Kendra Ganjam-

II Odisha University of

Agriculture and Technology,

Odisha, India

Kabita Mishra

Krishi Vigyan Kendra Ganjam-

II Odisha University of

Agriculture and Technology,

Odisha, India
Corresponding Author: Sushree Choudhury

Krishi Vigyan Kendra Ganjam-

II Odisha University of

Agriculture and Technology,

Odisha, India

\section{Response of integrated nutrient management on plant growth, flower yield and shelf life of african marigold (Tagetes erecta L.) cv. Pusa Narangi Gainda}

\author{
Sushree Choudhury, Debasis Sarangi and Kabita Mishra
}

DOI: https://doi.org/10.22271/chemi.2020.v8.i3ai.9577

\section{Abstract}

The present investigation entitled "Effect of Integrated nutrient management on Plant growth, Flower yield and shelf life of African Marigold (Tagetes erecta L.) c.v. Pusa Narangi Gainda, was under taken at K.V.K, Ganjam-II, Berhampur, odisha during the year 2016-17. The experiment was laid out in randomized block design with 8treatments replicated thrice. The treatments comprised of various combination of recommended dose of fertilizer i.e. RDF (120:80:80 kg NPK/ha), FYM (10t/ha), vermicompost (13t/ha), biofertilizers (Azotobacter, Azospirillum, Phosphobacterium @ $4 \mathrm{~kg} / \mathrm{ha}$ ) including control (no application of manure and fertiliser). The results revealed that application of $75 \%$ $\mathrm{RDF}+25 \%$ vermicompost+ Biofertilizers (T4) produced significantly maximum plant height $(77.44 \mathrm{~cm})$, number of primary and secondary branches per plant (16.40, 33.47 respectively), number of leaves per plant (198.27), earliest in days to first flower bud initiation (30.07) and days to first flowering (48.07), Also number of flowers per plant (34.07), flower diameter $(6.92 \mathrm{~cm})$, flowering duration $(54$ days), flower yield per plant $(315.42 \mathrm{~g})$ and flower yield per plot $(3.51 \mathrm{~kg})$, flower yield per hectare $(16.65 \mathrm{t})$ as compared to control and with application of $50 \% \mathrm{RDF}+50 \%$ vermicompost+ Biofertilizers (T6) showed maximum shelf life (7.75 days) of flowers at room temperature.

Keywords: Farmyard manure, RDF, vermicompost, biofertilizer, flower yield, marigold

\section{Introduction}

Flowers are important for their economic use as well as aesthetic value. Among the flowers grown by farmers, marigold (Tagetes erecta L.) has its own importance. It has gained popularity among flower growers because of its easy cultivation and wide adaptability, short duration to produce marketable flowers and good keeping quality. There is a constant demand for theses flowers throughout the year for various functions, festivals and floral decorations. Increased flower production, quality of flowers and perfection in the form of plants are the important objectives to be reckoned in commercial flower production. Though the quality of flowers is primarily a varietal trait, it is greatly influenced by climatic, geographical and nutritional factors. Marigold is also a heavy feeder of nutrients. At present the nutrients are supplied through chemical fertilizers. Indiscriminate and continuous use of chemical fertilizer in intensive cropping system has led to an imbalance of nutrients in soil which has an adverse effect on soil health and also affecting flower yield. It is impossible to meet the nutritional requirement of the crops, exclusively through the organic farming. Under these circumstances, integrated soil fertility management practices involving judicious combination of organic manures, bio fertilizers and chemical fertilizers seems to be a feasible option for sustained agriculture on a commercial and profitable scale. Now days, beneficial microbes has been integrated in balanced fertilization in worldwide. Farm Yard Manure (FYM) is the most common organic manure used in India. On an average well decomposed FYM contains 0.5 per cent N, 0.2 per cent $\mathrm{P} 2 \mathrm{O} 5$ and 0.5 per cent $\mathrm{K} 2 \mathrm{O}$. Biofertilizer can play a vital role in achieving sustainable production at low cost and act as replacement of chemical fertilizer as they contribute as plant nutrients through biological nitrogen fixation and solubilization of immobile phosphorus (Kumar et al 2006) ${ }^{[3]}$. Vermicompost could release nutrients slowly and steadily into the system and enables the plants to absorb these nutrients over time as reported 
by Sharma (2003) ${ }^{[6]}$. In addition, they are eco-friendly, easily available and cost effective. Therefore, emphasis is now focused on the use of fertilizer and organic manures such as farmyard manures, vermicompost and bio-fertilizers like Azotobacter, Azospirillum, Phosphobacterium, etc.

An integrated approach recognizes that soils are the storehouse of most of the plant nutrients essential for plant growth and that the way in which nutrients are managed will have a major impact on plant growth, soil fertility, and agricultural sustainability. Hence, the present investigation was under taken with the objectives to find out optimum level of inorganic NPK and to evaluate the integrated approaches of organic and biofertilizer nutrient source on the performance of marigold.

\section{Materials and Methods}

The present investigation was conducted at instructional farm of K.V.K, Ganjam-II, Berhampur, odisha during 2016-17 under open field condition. The experimental land was divided into small plots of size $2.0 \times 1.8 \mathrm{~m}$. One month old seedlings of African marigold cv. Pusa Narangi Gainda having uniform size and vigor were transplanted at a spacing of $45 \mathrm{~cm} \times 45 \mathrm{~cm}$. The treatments comprised of various combination of recommended dose of fertilizer i.e. RDF (120:80:80 kg NPK/ha), FYM (10t/ha), vermicompost i.e.VC (13t/ha), biofertilizers (Azotobacter, Azospirillum, Phosphobacterium @ $4 \mathrm{~kg} / \mathrm{ha}$ ) were applied as T1(Control i.e. no application of chemical and fertiliser), T2(100\%RDF.), T3 $(75 \%$ RDF+25\%FYM+ biofertilizers), $\mathrm{T} 4(75 \% \mathrm{RDF}+25 \% \mathrm{VC}+$ biofertilizers $), \mathrm{T} 5$ (50\% RDF $+50 \%$ FYM + biofertilizers), T6(50\% RDF $+50 \% \mathrm{VC}+$ biofertilizers), $\mathrm{T} 7(25 \% \mathrm{RDF}+75 \% \mathrm{FYM}+$ biofertilizers $)$, $\mathrm{T} 8(25 \% \mathrm{RDF}+75 \% \mathrm{VC}+$ biofertilizers $)$. The experiment was laid out in randomized block design with eight treatments and three replications. The organic manures were applied 10 days prior to transplanting, for proper decomposition, where as the bio-fertilizers (Azotobacter, Azospirillum, Phosphobacterium) were applied at the time of transplanting. Full dose of phosphorus and potassium and half dose of nitrogen as per treatment were applied one week after transplanting. The remaining half dose of nitrogen was supplied in one split doses at 30 days after transplanting. The cultural operations like irrigation, hoeing and weeding, plant protection measures were done from time to time to raise a good crop. The growth, flowering and yield parameter were recorded and analysed statistically to draw logical conclusions.

\section{Results and Discussion}

Various growth, flowering, and yield parameters were significantly affected by different doses of NPK, Farm yard manure, vermicompost, and biofertiliser.

\section{Effect of INM on vegetative parameters of African marigold}

The data presented in Table-1 shows that significant difference in all the growth parameters were recorded due to application of different combinations of nutrients. The maximum plant height $(77.44 \mathrm{~cm})$, number of primary branches (16.4), number of secondary branches (33.47) and number of leaves (209.6) were recorded in with T4 $(75 \% \mathrm{RDF}+25 \% \mathrm{VC}+$ Biofertilizers) followed by $\mathrm{T} 3,(75 \%$ $\mathrm{RDF}+25 \% \mathrm{FYM}+$ Biofertilizers) with plant height $(72.90 \mathrm{~cm})$, number of primary branches (14.27), number of secondary branches (29.8) and number of leaves (198.27) respectively. However minimum plant height $(57.40 \mathrm{~cm})$, number of primary branches (6.59), number of secondary branches (17.42), and number of leaves (139.23) were recorded in control $\mathrm{T} 1$.

The increase in vegetative growth in the treatments T4 due to the effect of optimum level of NPK, biofertilizers and FYM which leads to increased level of nutrients to plant which might have enhanced the cell division and cell elongation and increase in metabolic activities in the plants. Further, it might have resulted in breaking of apical dominance and thus sprouting of axillary buds leading to more number of branches per plant. More number of secondary branches and leaves may be due to the effect of biofertilizers which produce the growth promoting substances such as IAA, gibberellins which enhances the soil fertility with balanced dose of inorganic fertilizers which ultimately influences increase growth and development. It is in conformity with the findings of Kumar et al., (2009) ${ }^{[4]}$ in African marigold and Naik et al., (2014) ${ }^{[5]}$ in carnation.

\section{Effect of INM on floral parameters of African marigold}

The different treatment combination of inorganic and organic fertilizers had significantly influenced the floral parameters (Table 2). Among all the treatments, T4 had recorded minimum days taken for $1 \mathrm{st}$ flower bud initiation (30.07days), 1 st flowering (48.07days) and maximum duration of flowering (54 days). Whereas, maximum days taken for $1 \mathrm{st}$ flower bud initiation (40.12days),first emergence of flower (58.02 days) and minimum duration of flowering (37.75days) were recorded under control respectively. The early flowering might be due to the application of vermicompost and azotobacter with nitrogen, phosphorus, potash fertilizer which accelerated protein synthesis for higher availability of nitrogen with azotobacter application. The improvement in flowering duration might be due to the combined doses of organic and inorganic fertilizers which improved the soil health, water retention capacity and availability of microbes. It is apparent from the data presented in Table- 2 that the application of the fertilizer and manure had promotive effect on flower diameter and number of flower per plant as compared to control.

The maximum flower diameter $(6.96 \mathrm{~cm})$ and number of flower (34.07) were recorded under the treatment T4, where crop was fertilized with a dose of $75 \%$ recommended dose of nitrogen, phosphorus, potash + 25\%Vermicompost+ biofertiliser (Azotobacter, Azospirillum, Phosphobacterium @ $4 \mathrm{~kg} / \mathrm{ha}$ each) followed by T3, while minimum flower diameter $(4.17 \mathrm{~cm})$ and number of flower plant-1 (23.2) were noticed under the control T1. The beneficial effect of nitrogen and phosphorus nutrient on flower size might be due to that nitrogen increase the protein synthesis, thus promote the development of floral primordial, while phosphorus found to be involved in formation of floral premodial resulting more number of flower obtained. 
Table 1: Effect of integrated nutrient management on vegetative parameters of African marigold cv. Pusa Narangi Gainda

\begin{tabular}{|c|c|c|c|c|}
\hline Treatments & Plant height & Primary branches & Secondary branches & Number of leaves \\
\hline T1: CONTROL & 57.40 & 6.59 & 17.42 & 139.23 \\
\hline T2: $100 \%$ RDF & 67.33 & 10.93 & 29.2 & 179.4 \\
\hline T3: $75 \%$ RDF+25\%FYM+ Biofertilizers & 72.90 & 14.27 & 29.8 & 198.27 \\
\hline T4: 75\%RDF+25\%VC+ Biofertilizers & 77.44 & 16.4 & 33.47 & 209.6 \\
\hline T5: 50\% RDF + 50\% FYM + Biofertilizers & 68.13 & 11.2 & 27.6 & 179.97 \\
\hline T6: $50 \%$ RDF + 50\% VC + Biofertilizers & 71.12 & 13.6 & 29.53 & 189.17 \\
\hline T7: $25 \%$ RDF + 75\% FYM+ Biofertilizers & 64.40 & 8.33 & 25.3 & 161.7 \\
\hline $\mathrm{T} 8: 25 \% \mathrm{RDF}+75 \% \mathrm{VC}+$ Biofertilizers & 66.33 & 9.73 & 26.63 & 179.47 \\
\hline $\mathrm{SE}(\mathrm{m})$ & 0.95 & 0.46 & 0.42 & 0.90 \\
\hline CD 5\% & 2.88 & 1.40 & 1.28 & 2.74 \\
\hline
\end{tabular}

Table 2: Effect of integrated nutrient management on floral parameters of African marigold cv. Pusa Narangi Gainda

\begin{tabular}{|c|c|c|c|c|c|}
\hline Treatments & $\begin{array}{c}\text { Days to 1st Flower } \\
\text { Bud Initiation (Days) }\end{array}$ & $\begin{array}{c}\text { Days To 1st } \\
\text { Flowering (Days) }\end{array}$ & $\begin{array}{c}\text { Flowering } \\
\text { Duration (Days) }\end{array}$ & $\begin{array}{c}\text { No.Of Flower } \\
\text { Per Plant }\end{array}$ & $\begin{array}{c}\text { Flower } \\
\text { Diameter (Cm) }\end{array}$ \\
\hline T1: CONTROL & 40.12 & 58.02 & 37.75 & 23.2 & 4.17 \\
\hline T2: 100\% RDF & 32.93 & 51.4 & 48.47 & 30.6 & 5.63 \\
\hline T3: 75\% RDF+25\%FYM+ Biofertilizers & 30.93 & 49.8 & 49.23 & 32.27 & 6.10 \\
\hline T4: 75\%RDF+25\% VC+ Biofertilizers & 30.07 & 48.07 & 54 & 34.07 & 6.92 \\
\hline T5: 50\% RDF + 50\% FYM + Biofertilizers & 32.13 & 51.2 & 44.27 & 30.73 & 5.64 \\
\hline T6: 50\% RDF+ 50\% VC + Biofertilizers & 31.27 & 50.53 & 47.73 & 32 & 6.03 \\
\hline T7: 25\% RDF + 75\% FYM+ Biofertilizers & 34.6 & 54.73 & 41.43 & 28.07 & 5.46 \\
\hline T8: 25\% RDF+ 75\% VC + Biofertilizers & 32 & 52.07 & 42.3 & 29.93 & 5.55 \\
\hline SE(m) & 0.62 & 0.51 & 0.48 & 0.63 & 0.32 \\
\hline CD 5\% & 1.87 & 1.56 & 1.47 & 1.90 & 0.97 \\
\hline
\end{tabular}

Table 3: Effect of integrated nutrient management on yield and shelf life of flower of african marigold cv. pusa narangi gainda

\begin{tabular}{|c|c|c|c|c|}
\hline Treatments & $\begin{array}{c}\text { Flower Yield Per } \\
\text { Plant (g) }\end{array}$ & $\begin{array}{c}\text { Flower Yield Per } \\
\text { Plot (kg) }\end{array}$ & $\begin{array}{c}\text { Flower Yield Per Hector } \\
\text { (t) }\end{array}$ & $\begin{array}{c}\text { Shelf Life of Flower } \\
\text { (Days) }\end{array}$ \\
\hline T1: CONTROL & 145.03 & 1.37 & 8.17 & 3.18 \\
\hline T2: 100\% RDF & 226.08 & 2.48 & 12.23 & 5.98 \\
\hline T3: 75\% RDF+25\%FYM+ Biofertilizers & 269.11 & 2.87 & 14.14 & 6.56 \\
\hline T4: 75\%RDF+25\% VC+ Biofertilizers & 315.42 & 3.51 & 16.65 & 6.45 \\
\hline T5: 50\% RDF + 50\% FYM + Biofertilizers & 204.94 & 2.36 & 11.3 & 5.72 \\
\hline T6: 50\% RDF + 50\% VC + Biofertilizers & 264.58 & 2.83 & 13.95 & 7.75 \\
\hline T7: 25\% RDF + 75\% FYM+ Biofertilizers & 156.7 & 1.91 & 10.14 & 5.78 \\
\hline T8: 25\% RDF + 75\% VC + Biofertilizers & 213.5 & 2.37 & 11.67 & 5.96 \\
\hline SE(m) & 0.56 & 0.18 & 0.38 & 0.29 \\
\hline CD 5\% & 1.71 & 0.55 & 1.17 & 0.89 \\
\hline
\end{tabular}

\section{Effect of INM on Yield and Shelf Life Of Flower of African marigold flowers}

Data presented inTable-3 showed that the various recommended doses of nitrogen, phosphorus, potash, manure and biofertilizer application gave the significant effect on the flower yield plant $-1(\mathrm{~g})$, flower yield plot $-1(\mathrm{~kg})$,yield of flower tonnes ha-1. Maximum flower yield per plant, per plot and per hectare $(315.42 \mathrm{~g}, 3.51 \mathrm{~kg}$ and $16.65 \mathrm{t}$, respectively) was obtained in $\mathrm{T} 4(75 \% \mathrm{RDF}+25 \% \mathrm{VC}+$ Biofertilizers $)$ whereas minimum results for these parameters were found in T1. It might be due to the fact that bio-fertilizers enhance growth promoting substances such as IAA, gibberellins vitamins, riboflavins etc. which might have enhanced the soil fertility. Bio-fertilizer when applied with organic and inorganic fertilizers has increased the availability of essential plant nutrients which might have enhanced root and shoot development thereby increasing the plant growth as well as number of branches which directly stimulate flower yield.
Thereafter it might have influenced the reproductive phase and induced flowering which resulted in increased number of flower yield per plant, per plot and per hectare. The flower yield decreased with every decreased per cent of recommended of nitrogen, phosphorus, potash with increasing level of manure and biofertiliser. These findings are supported

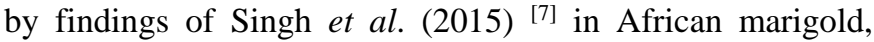
Airadevi et al., (2012) ${ }^{[1]}$ in garland chrysanthemum

Longest shelf life (7.75Days) was reported in plants treated with T6 (50\% RDF + 50\% VC + Biofertilizers) while minimum was recorded under control T1. Increased shelf life may be due to optimum food nutrient availability from different organic and inorganic sources which might have resulted in greater development of water conducting tissue with high level of water retention in the cells of flowers thereby lowering the desiccation. Similar findings have been reported by Khanna et al., (2016) ${ }^{[2]}$ in China aster and Verma et al., (2011) ${ }^{[8]}$ chrysanthemum. 


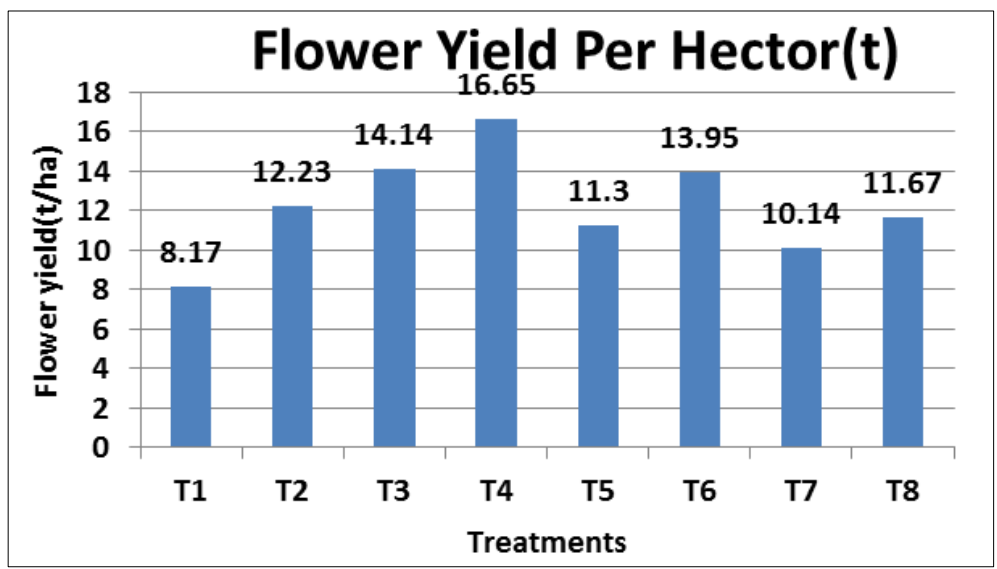

Fig 1: Effect of integrated nutrient management on yield of african marigold cv. pusa narangi gainda

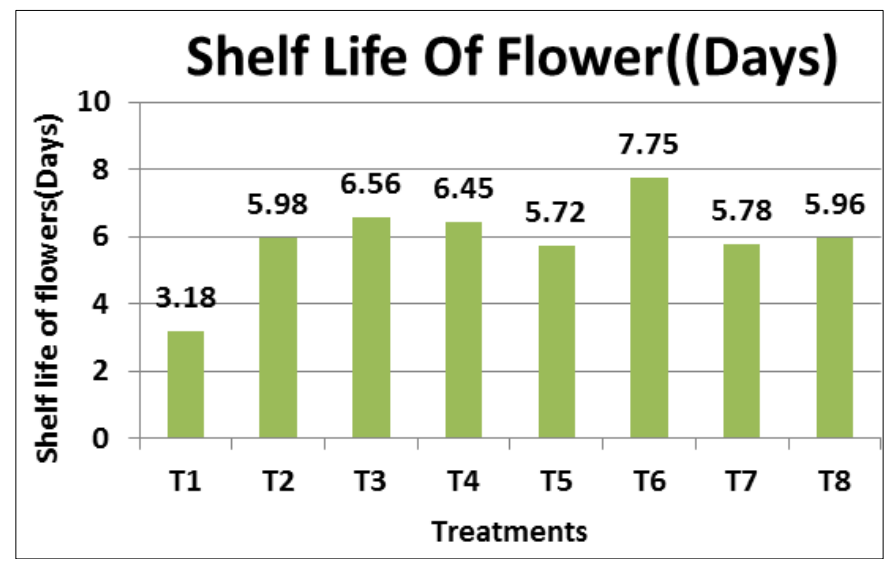

Fig 2: Effect of integrated nutrient management on Shelf life of african marigold cv. pusa narangi gainda

\section{Conclusion}

The present study clearly indicates that vermicompost and biofertiliser may be an efficient plant growth media for sustainable growth and flower production, if applied with some combination of NPK. It could be concluded from the present investigation that for higher quantity and quality production of marigold flowers, application of $75 \%$ inorganic $+25 \%$ organic was most effective. Hence to maximize production of quality flowers in marigold application of $75 \%$ recommended dose of nitrogen, phosphorus, potash along with 25\%vermicompost and biofertiliser (Azotobacter, Azospirillum, Phosphobacterium @ 4 kg/ha each is advisable.

\section{References}

1. Airadevi PA, Mathad JC. Effect of INM on growth, yield and economics of garland chrysanthemum. Asian Journal of Soil Science. 2012; 7(1):93-97.

2. Khanna P, Rajesh Bohra M, Punetha P, Nautiyal BP. Studies on the effect of organic manures and PSB on vegetative and floral parameters of China aster (Callistephus chinensis (L.) ness.) cv. Kamini under mid hills region of Himalaya. The Bioscan. 2016; 11(4):27072710.

3. Kumar AV, Natrajan N. Nutrient management and flower position on seed quality in marigold. Advance in Plant Sciences. 2006; 19(1):37-40.

4. Kumar D, Singh BP, Singh VN. Effect of integrated nutrient management on growth, flowering behaviour and yield of African marigold (Tagetes erecta L.) cv. African Giant Double Orange. Journal of Horticultural Sciences. 2009; 4(2):134137.
5. Naik BH, Dalawai B. Integrated nutrient management studies in carnation (Dianthus caryophyllus L.) cv. Soto under protected condition. International Journal of Agricultural Sciences and Veterinary Medicines. 2014; 2(3):19-24

6. Sharma AK. Biofertilizers for Sustainable Agriculture. Updesh Purohit for Agrobios, Jodhpur, 2003, 41-46.

7. Singh P, S Prakash, Mukesh Kumar, Sunil Malik, Manoj Kumar Singh, Arvind Kumar et al. Eff ect of integrated nutrient management (INM) on growth, flowering and yield in marigold (Tagetus erecta L.) Cv. "Pusa Basanti" Annals of Horticulture. 2015; 8(1):73-80.

8. Verma SK, Angadi SG, Patil VS, Mokashi AN, Mathad JC, Mummigatti UV et al. Growth, yield and quality of chrysanthemum (Chrysanthemum morifolium Ramat.) cv. Raja as influenced by integrated nutrient management. Karnataka Journal of Agricultural Sciences. 2011; 24(5):681-683. 